\title{
Rancangan Sistem Informasi Peminjaman dan Pengembalian Buku Pada Perpustakaan XYZ Dengan Metodologi Berorientasi Obyek
}

\author{
Robby Rizki \\ Universitas Mathla'ul Anwar \\ J1. Raya Labuan Km. 23 Cikaliung, Pandeglang, Banten, 42273 \\ Robby_ba87@yahoo.com
}

\begin{abstract}
Abstraksi- Perpustakaan XYZ adalah perpustakaan yang sama dengan perpustakaan sekolah tinggi lain pada umumnya, yang difungsikan sebagai media untuk mencari refrensi dan informasi untuk menambah ilmu pengetahuan. Proses penyusunan laporan dan evaluasi inventori yang masih menggunakan cara manual menjadi salah satu penyebab terhambatnya proses pembuatan laporan peminjaman, efisiensi waktu pengerjaan lama, ketepatan dalam melakukan proses peminjaman, serta frekuensi kebutuhan akan informasi atau laporan kurang tepat dan akurat. Tujuan dari penulis dalam penelitian ini adalah untuk menganalisis, merancang dan mengimplementasikan sistem sirkulasi perpustakaan XYZ menjadi terkomputerisasi untuk mengatasi masalah yang ada. Oleh karena hal tersebut diatas, penulis merasa bahwa sistem komputerisasi sangat dibutuhkan untuk mengendalikan sistem peminjaman buku yang dilakukan oleh XYZ tersebut. Sehingga layanan kebutuhan informasi terhadap kesedian buku yang ada diperpustakaan XYZ dapat melayani transaksi sirkulasi data (peminjaman, pengembalian), data pencarian buku dan pembuatan laporan menjadi lebih cepat, akurat dan tepat waktu. Penulis berharap bahwa penulisan ini dapat berguna bagi XYZ dalam mengembangkan perpustakaan XYZ.
\end{abstract} Objek

Kata Kunci-Sistem Informasi, Perpustakaan, Berorientasi

\section{Pendahuluan}

Sebuah Institusi Pendidikan dalam menyelenggarakan belajar mengajar tidak terlepas dari peran dan fungsi perpustakaan. Keberadaan perpustakaan seharusnya juga mendapat perhatian agar selalu dikembangkan sejalan dengan perkembangan teknologi supaya tidak ketinggalan dan dapat terus menjalankan peran dan fungsinya. Bahkan sebagai ukuran perkembangan perpustakaan saat ini banyak diukur dari penerapan teknologinya, bukan dari sekala ukuran lain seperti besarnya gedung yang digunakan, jumlah koleksi atau jumlah penggunanya.

Penerapan teknologi informasi di perpustakaan dapat difungsikan dalam berbagai bentuk, antara lain sebagai Sistem Informasi Manajemen Perpustakaan. Adapun tujuannya untuk mempermudah dan mempercepat operasional kerja yang berkaitan dengan kegiatan serta masalah pengolahan data pada perpustakaan XYZ merupakan salah satu Sekolah Tinggi Ilmu Kesehatan yang harus terus dikembangkan seiring dengan perkembangan dan kemajuan teknologi, serta bertambahnya koleksi dan anggota sudah waktunya perpustakaan XYZ memanfaatkan sistem yang terkomputersasi guna membantu operasionalnya.

Untuk mengatasi hal itu disini penulis mencoba mengajukan sistem perpustakaan yang terkomputerisasi untuk mempermudah pekerjaan pada Perpustakaan XYZ.

\section{LANDASAN TEORI}

\section{A. Konsep Sistem Informasi}

Seperti yang didefinisikan oleh seorang penulis "Sistem adalah kumpulan dari elemen-elemen yang berinteraksi untuk mencapai suatu tujuan tertentu" [1]. Demikian juga mengenai pengertian sistem, sebagai berikut "Sistem adalah sebuah tatanan (keterpaduan) yang terdiri atas sejumlah komponen fungsional (dengan satuan fungsi atau tugas khusus) yang saling berhubungan dan secara bersama-sama bertujuan untuk memenuhi suatu proses atau pekerjaan tertentu" [2].

Komponen-komponen atau subsistem-subsistem dalam suatu sistem tidak dapat berdiri sendiri, komponen-komponen tersebut saling berhubungan membentuk satu kesatuan sehingga tujuan (goal) atau sasaran (objectives) sistem tersebut dapat tercapai.

\section{1) Konsep Dasar Sistem dan Informasi}

Dalam sistem informasi, terdapat inti dan tujuan, yaitu menghasilkan informasi itu sendiri. Sesederhana apa pun sistem informasi dikembangkan, jika bisa menghasilkan informasi yang diharapkan, maka pengembangannya dikatakan berhasil. Namun dilain pihak, secanggih apapun sistem informasi yang dikembangkan, jika tidak dapat menghasilkan informasi yang diharapkan maka pengembangannya dikatakan gagal.

2) Konsep Dasar Sistem Informasi 
Sistem adalah sekelompok dua atau lebih komponenkomponen yang saling berkaitan (inter-related) atau subsistem-subsistem yang bersatu untuk mencapai tujuan yang sama (common purpose). Sistem informasi (informasi system) adalah sebuah rangkaian prosedur formal dimana data dikumpulkan, diproses menjadi informasi dan didistribusikan kepada para pemakai.

Telah diketahui bahwa informasi merupakan hal yang sangat penting bagi manajemen di dalam mengambil keputusan. Pertanyaannya adalah dari mana informasi tersebut bisa didapatkan? Informasi dapat diperoleh dari sistem informasi atau disebut juga dengan processing systems.

Sistem informasi didefinisikan sebagai berikut "Sistem informasi adalah Satuan komponen yang saling berhubungan yang memproses ,menyimpan, dan mendistribusikan informasi untuk mendukung pengambilan keputusan dan kendali dalam suatu organisasi”. [3]

\section{B. Analisa dan Perancangan Sistem Berorientasi Obyek} dengan UML

1) UML (Unified Modelling Language)

UML adalah sebuah "bahasa pemodelan" yang menspesifikasikan, menvisualisasikan, membangun dan mendokumentasikan kerangka dari sebuah sistem software.

Menurut pencetusnya, UML di definisikan sebagai bahasa visual untuk menjelaskan, memberikan spesifikasi, merancang, membuat model, dan mendokumentasikan aspek-aspek dari sebuah sistem.

UML merupakan salah satu alat bantu yang handal di dunia pengembangan sistem berorientasi objek. Hal ini karena UML menyediakan bahasa pemodelan visual yang mendukung bagi pengembangan sistem untuk membuat cetak biru atas visi mereka dalam bentuk baku, mudah dimengerti serta dilengkapi dengan mekanisme yang efektif untuk berbagi dan mengkomunikasikan rancangan mereka dengan yang lain (seperti mengkomunikasikan kepada calon pengguna sistem dan pemrogram).

\section{2) Analisa Sistem Berorientasi Obyek}

Analisa sistem adalah suatu proses untuk mengidentifikasi dan mengevaluasi permasalahan permasalahan, penyebab - penyebab masalah, mengidentifikasi kebutuhan-kebutuhan sistem, dan memahami secara keseluruhan tentang sistem yang akan kita kembangkan.

Melakukan kajian, dan menemukan berbagai faktor dari prosedur penyelenggaraan pengolahan data yang berlangsung saat ini untuk bisa memenuhi kebutuhan akan sistem informasi efektif, itulah yang menjadi titik berat dari sebuah proses penganalisaan akan sebuah sistem yang akan dikomputerisasikan.

Keberhasilan dari tahap analisa adalah memahami kebutuhan-kebutuhan sistem dan membuat konsep sistem baru yang menggambarkan apa yang harus dilakukan sistem guna memenuhi kebutuhan-kebutuhan sistem.

Tujuan utama dari analisa berorientasi objek adalah memodelkan sistem yang nyata dengan penekanan apa yang harus dilakukan sistem.

Pada tahap analisa berorientasi objek, objek bisnis dalam sebuah sistem diidentifikasikan seperti siapa atau aktornya dan bagaimana mereka bekerja sama dalam aplikasi. Dalam hal ini penulis menggunakan use case untuk mengidentifikasikan apa yang akan pengguna kerjakan dengan sistem atau perangkat lunak yang akan dikembangkan dan mengidentifikasikan aktor termasuk didalamnya adalah siapa yang akan menggunakan sistem.

\section{3) Perancangan Sistem Berorientasi Obyek}

Perancangan sistem Berorientasi Objek merupakan tahap lanjutan setelah analisa berorientasi objek.

"Perancangan berorientasi objek adalah suatu pendekatan yang digunakan untuk menspesifikasikan kebutuhan - kebutuhan sistem dengan mengkolaborasikan objek - objek, atribut - atribut, method - method yang ada."'[4]

Merupakan proses spesifikasi yang terperinci atau pendefinisian dari kebutuhan-kebutuhan fungsional yang menggambarkan bagaimana suatu sistem itu dibentuk. Perancangan sistem berorientasi objek ditujukan untuk mensistematis proses pendesainan dan menghasilkan pendesainan model program. Serta memberikan gambaran pemecahan masukan dengan efektif.

\section{ANALISA SISTEM}

\section{A. Analisa Proses}

\section{1) Pendataan Buku}

Petugas perpustakaan mencatat data-data buku tersebut ke dalam buku besar. Data-data buku tersebut dijadikan arsip oleh petugas perpustakaan.

\section{2) Pendaftaran Anggota}

Petugas perpustakaan memberikan formulir anggota kepada calon anggota yang ingin menjadi anggota perpustakaan. Setelah mengisi lengkap formulir anggota, calon anggota menyerahkan kembali formulir kepada petugas perpustakaan. Petugas perpustakaan lalu membuat kartu anggota dan kartu peminjaman berdasarkan data dari formulir anggota lalu menyerahkannya kepada anggota.

\section{3) Proses Peminjaman Buku}

Anggota memilih buku yang akan dipinjam, kemudian anggota menyerahkan kartu Anggota, kartu pinjaman dan buku yang akan dipinjam. Petugas perpustakaan kemudian memeriksa buku peminjaman, jika ada peminjaman buku maka peminjaman ditolak dan jika tidak ada peminjaman buku maka petugas perpustakaan mencatat data peminjaman kebuku peminjaman, setelah itu petugas perpustakaan menyerahkan buku dan kartu peminjaman kepada anggota. 


\section{4) Proes Pengembalian Buku}

Anggota perpustakaan menyerahkan buku yang hendak dikembalikan kepada petugas perpustakaan. Petugas perpustakaan mengecek tanggal pengembalian buku. Bila anggota mengembalikan buku tepat waktu, petugas perpustakaan mencatat pengembalian buku pada buku besar. Bila anggota perpustakaan terlambat mengembalikan buku, petugas perpustakaan memberikan peringatan kemudian mencatat tanggal pengembalian pada buku besar. Kemudian petugas perpustakaan menyerahkan kartu anggota dan kartu peminjaman.

\section{5) Proses Pembuatan Laporan}

Secara berkala petugas perpustakaan membuat laporan peminjaman buku untuk diserahkan kepada Puket I.

\section{B. Activity Diagram}

\section{1) Pendataan Buku}

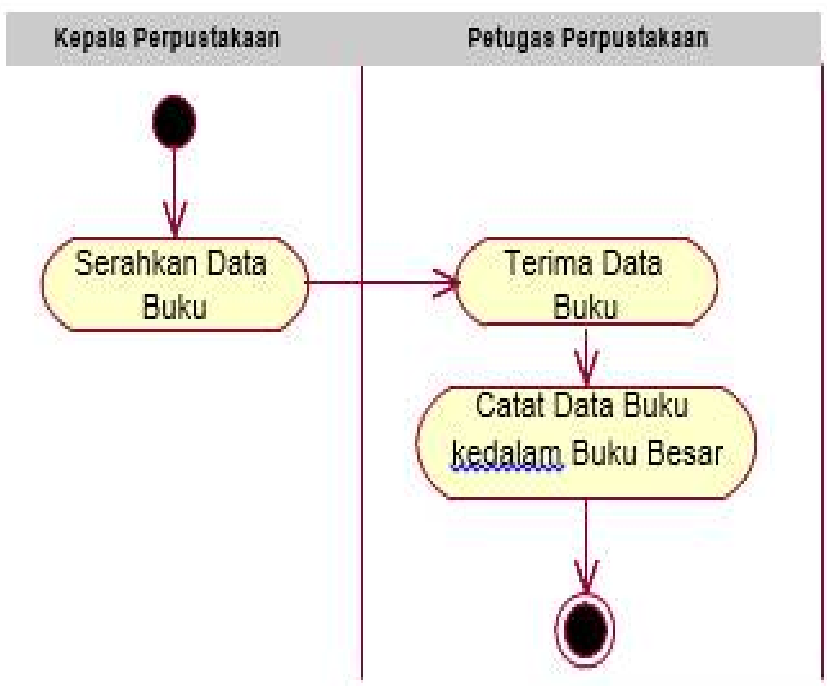

Gambar 1. Activity Diagram Pendataan Buku

2) Pendaftaran Anggota

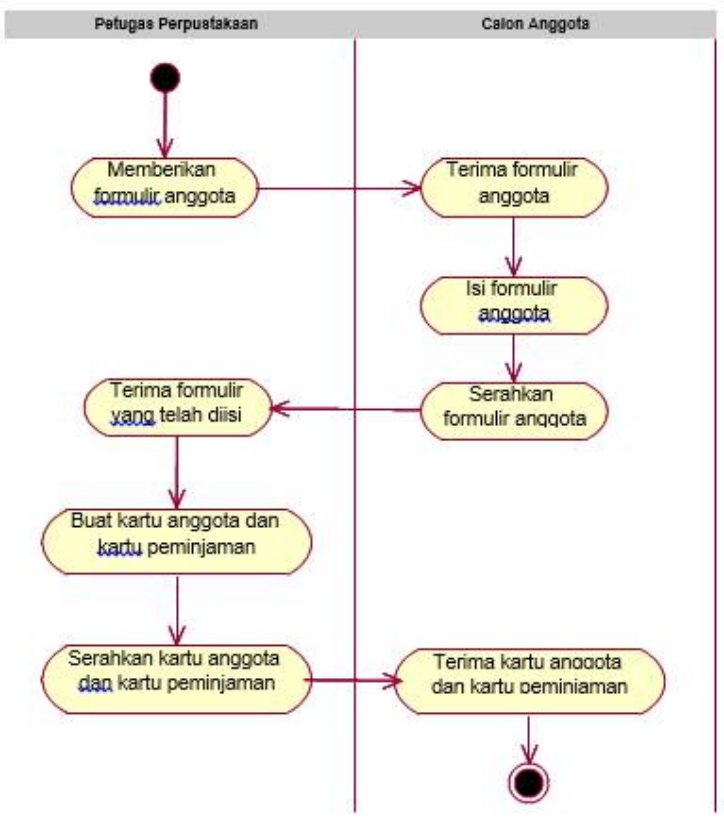

Gambar 2. Activity Diagram Pendaftaran Anggota

3) Proses Peminjaman Buku

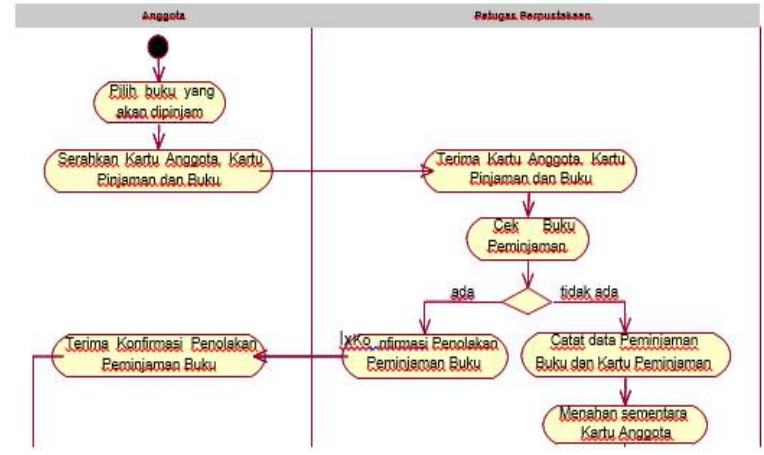

Gambar 3. Activity Diagram Peminjaman Buku

4) Pengembalian Buku

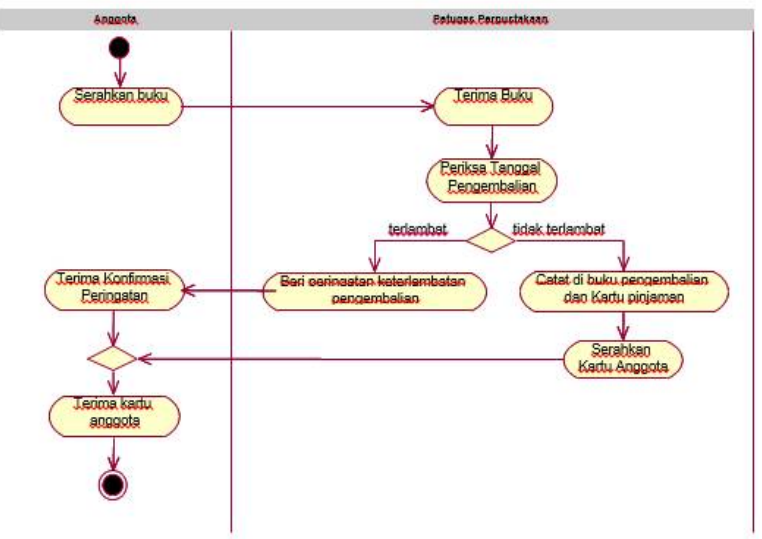

Gambar 4. Activity Diagram Pengembalian Buku 
C. Use Case

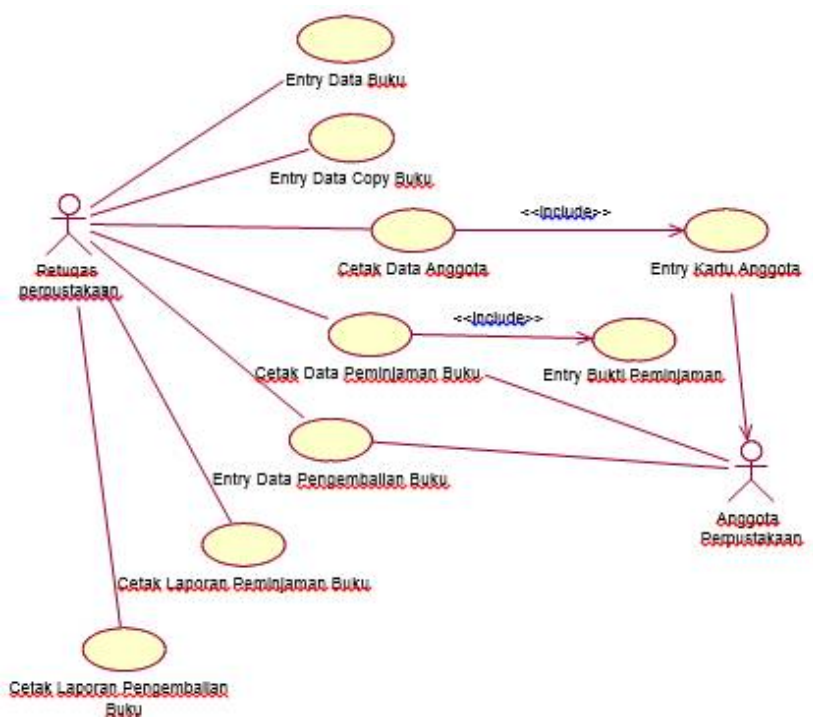

Gambar 5. Use Case Diagram Sistem Usulan

\section{RANCANGAN SISTEM}

\section{A. Rancangan Basis Data}

Rancangan Basis Data Dalam merancang sistem yang terkomputerisasi, sebaiknya seluruh data yang akan dipergunakan oleh sistem tersebut disimpan ke dalam suatu basis data yang memiliki kelebihan data independent. Dengan menerapkan suatu basis data dalam strategi akses dalam pengembangan sistem tanpa harus mengubah programprogram aplikasi yang sudah ada. Langkah yang harus dilakukan dalam pembentukan suatu basis data yang baik adalah sebagai berikut :

\section{1) Entity Relationship Diagram}

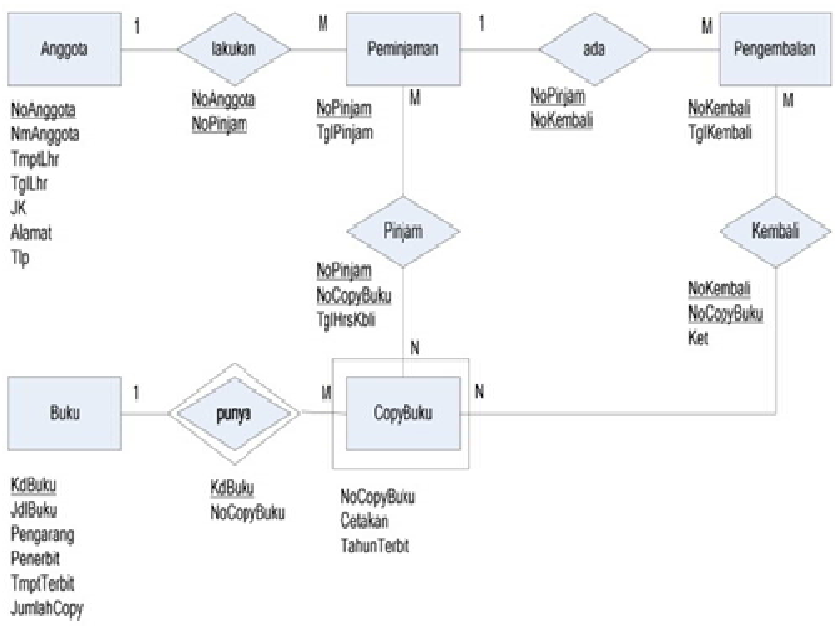

Gambar 6. Entity Relationship Diagram
2) Transformasi Diagram ER ke Logical Record Structure

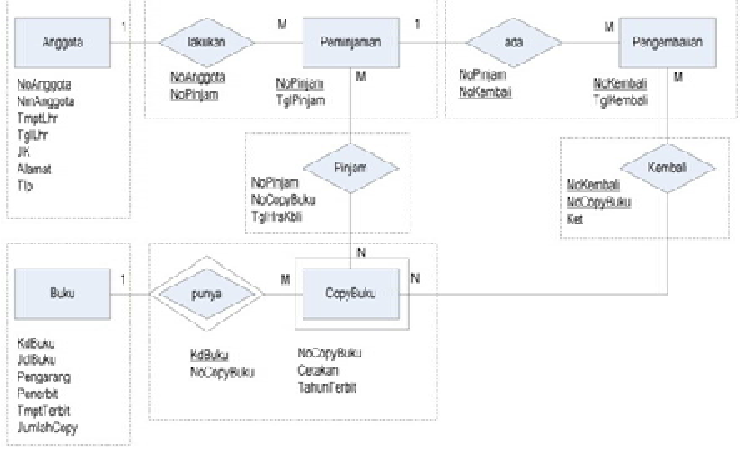

Gambar 7. Transformasi ERD ke LRS

3) Logical Record Structure (LRS)

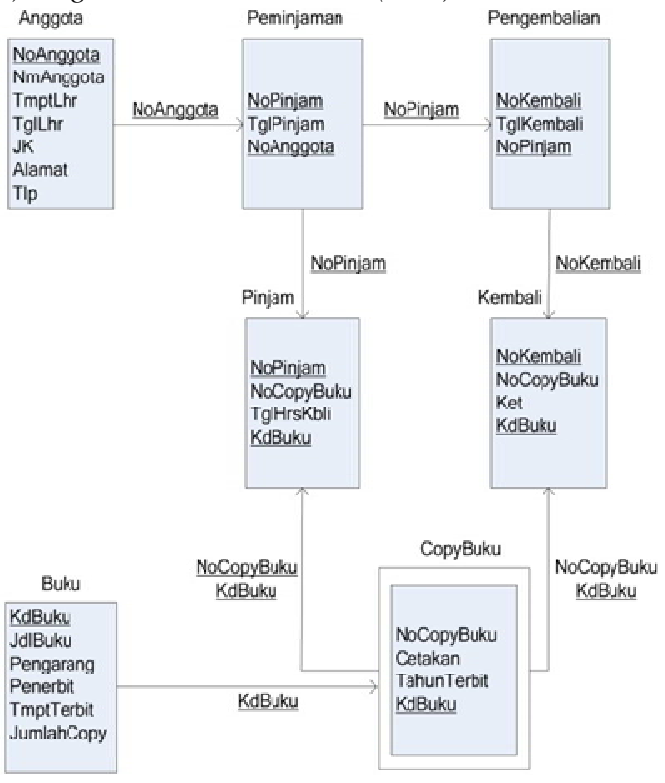

Gambar 8. LRS

B. Rancangan Layar

1) Form Menu Utama

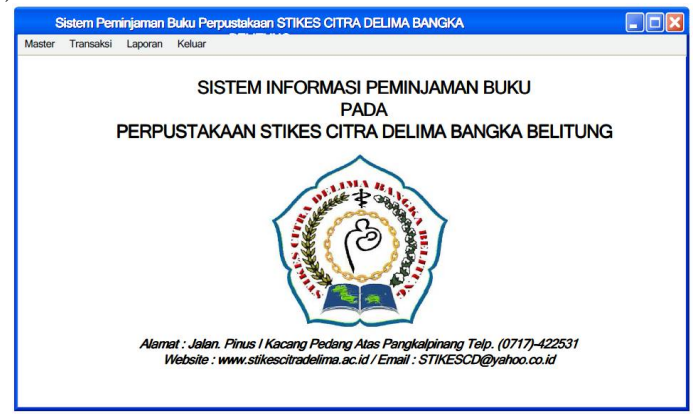

Gambar 9. Tampilan Layar Entry Data Pelanggan 


\section{2) Form Menu Master}

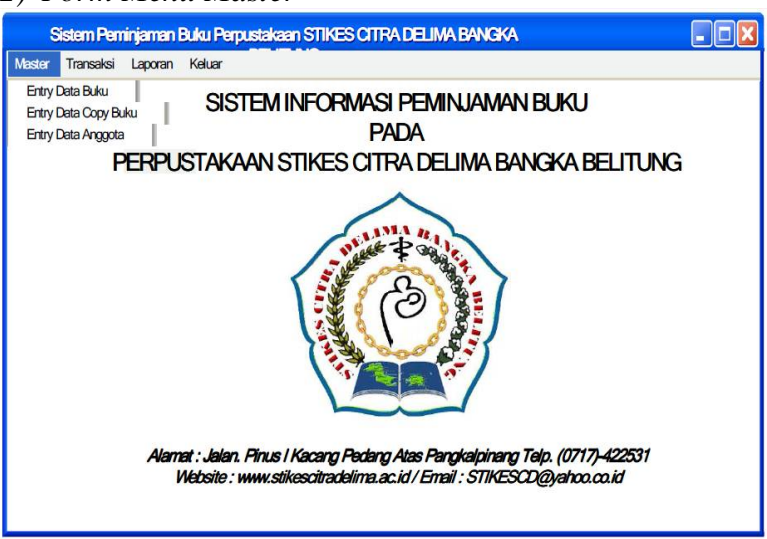

Gambar 10. Tampilan Layar Form Menu Master

\section{3) Form Entry Buku}

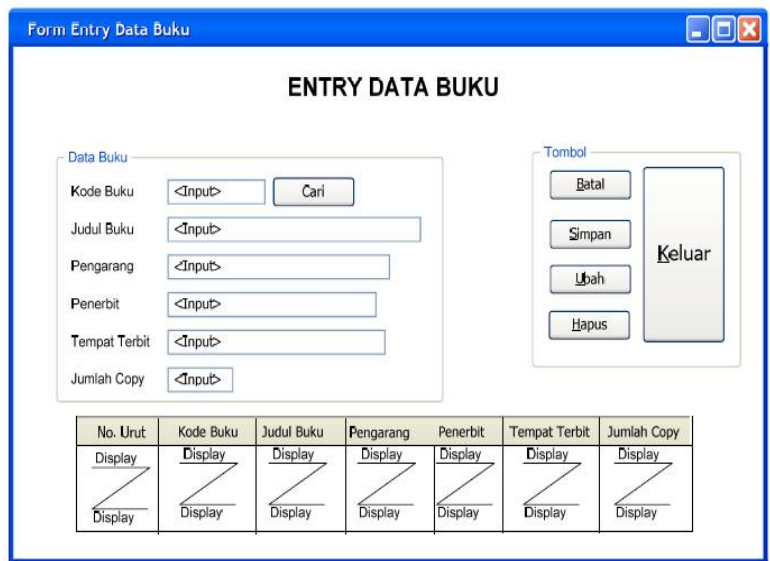

Gambar 11. Tampilan Layar Form Entry Buku

4) Form Entry Data Anggota

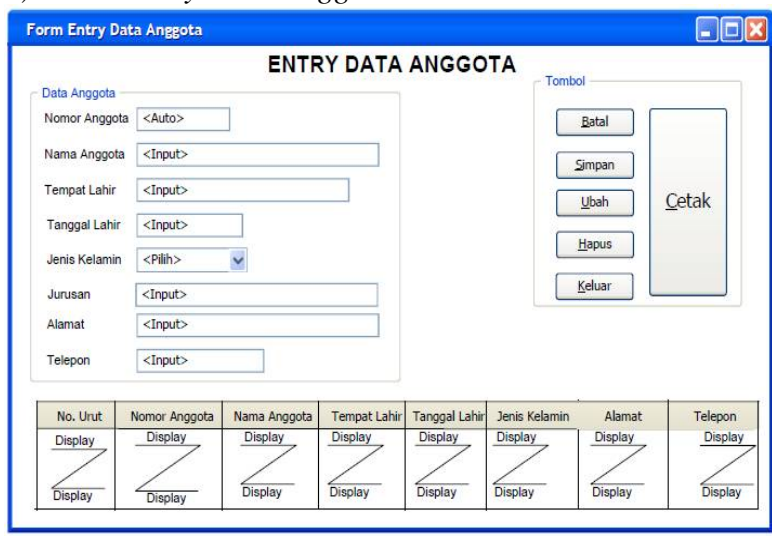

Gambar 12. Tampilan Layar Entry Data Anggota
5) Entry Data Peminjaman

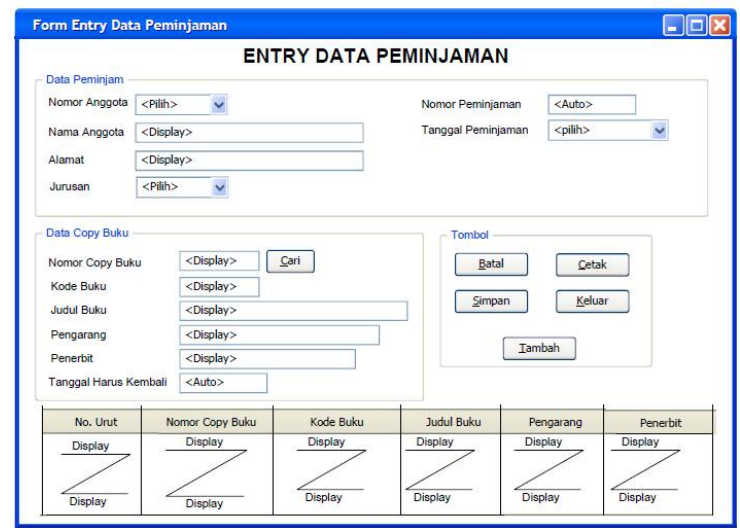

Gambar 13. Tampilan Layar Entry Data Peminjaman

6) Entry Data Pengembalian

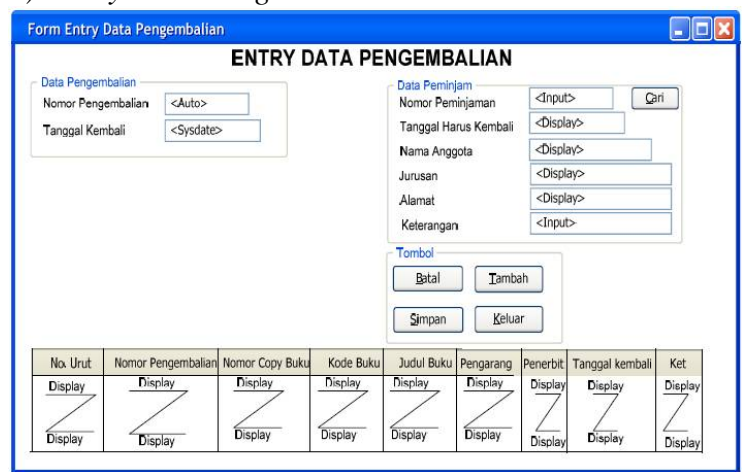

Gambar 14. Tampilan Layar Entry Data Pengembalian

7) Cetak Laporan Peminjaman

Cetak Laporan Peminjaman $\square \square x$

Cetak Laporan Peminjaman?

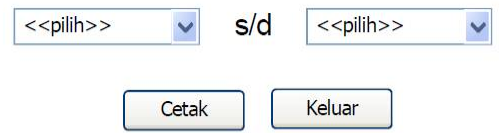

Gambar 15. Tampilan Layar Cetak Laporan Peminjaman

8) Cetak Laporan Pengembalian

Cetak Laporan Pengembalian

$\square \square x$

Cetak Laporan Pengembalian?

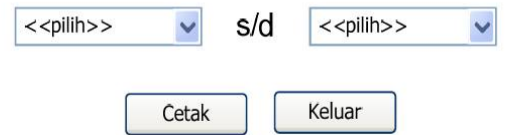

Gambar 16. Tampilan Layar Cetak Laporan Pengembalian 


\section{Rancangan Class Diagram (Entity Class)}

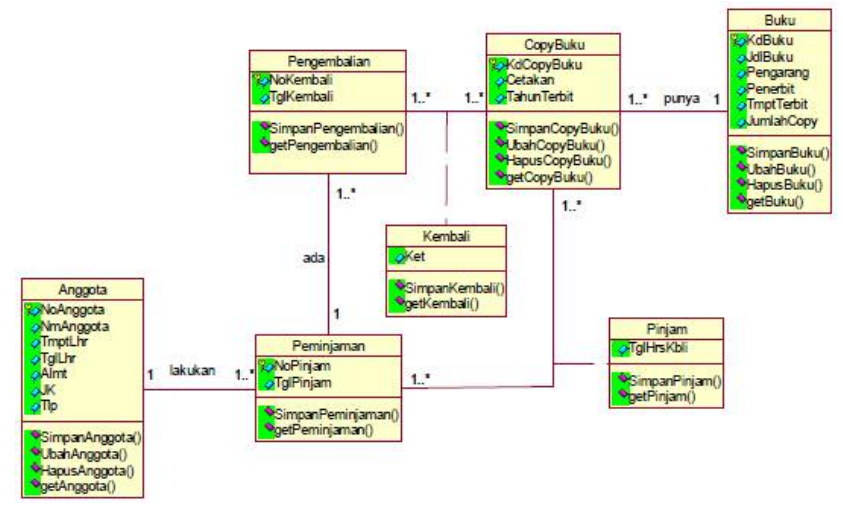

Gambar 17. Rancangan Class Diagram

\section{Penutup}

\section{A. Kesimpulan}

Setelah melakukan riset pada perpustakaan XYZ, maka dapat disimpulkan sebagai berikut:

- Sistem perpustakaan yang berbasis komputer sangat dibutuhkan agar dapat membantu dalam menangani permasalahan yang ada.

- Dengan adanya sistem perpustakaan yang terkomputerisasi dapat memudahkan dalam pengontrolan data peminjaman buku yang ada.

- Adanya sistem yang terkomputerisasi diharapkan dapat mempermudah dan memperlancar setiap transaksi peminjaman buku.

- Pengolahan data yang menggunakan komputer dapat memberikan informasi dan laporan yang lebih cepat dan akurat dibandingkan dengan sistem manual sehingga akan sangat membantu bagi tingkat manajemen dalam pengambilan keputusan.

\section{B. Saran}

Hasil dari Tugas Akhir ini adalah aplikasi sistem informasi perpustakaan pada XYZ, yang didalamnya berisi tentang peminjaman buku. Mengingat pentingnya pengolahan data perpustakaan dengan baik maka dibutuhkan sumber daya manusia yang tepat selain sistem informasi yang akurat untuk mendukung kelancaran sistem perpustakaan.

Oleh karena itu sebaiknya menggunakan sistem komputer yang sudah terintegrasi demi kelancaran dan keakuratan informasi yang dihasilkan.

Penulis berharap rancangan sistem informasi perpustakaan ini dapat membantu permasalahan yang dihadapi oleh perpustakaan XYZ.

\section{DAFTAR PUSTAKA}

[1] Jogiyanto, Analisis dan Desain Sistem Informasi : Pendekatan Terstruktur Teori dan Praktik Aplikasi Bisnis. Yogyakarta : ANDI, 2001.

[2] Fathansyah, Basis Data. Bandung : Informatika, 2001

[3] Kendall, Kenneth E., and Julie E. Kendal, Analisa dan Perancangan Sistem. Edisi ke 5. Jakarta : PT Indeks Kelompok Gramedia, 2003.

[4] Whitten, Jeffrey L., Lonnie D. Bentley, Kevin C.Dittman. System Analysis and Design Methods. 6th ed. New York : McGraw-Hill, 2004.

[5] Mulyadi. Sistem Akuntansi. Edisi 2. Yogyakarta : YKPN, 2001.

[6] Widjayanto, Nugroho. Sistem Informasi Akuntansi. Jakarta : Erlangga, 2001.

[7] George, H. Bodnar. Akuntansi.Jakarta : PT. Garamedia Widiasarana Indonesia, 2006.

[8] Harahap, Sofyan Syafri. Teori Akuntansi. Jakarta : PT. Raja Graffindo Persada, 2002. 